\title{
Project Management and Performance of Rural Road Construction Projects in Machakos County, Kenya
}

\author{
Cornelius Wandiri, \\ Postgraduate student, School of Business, Kenyatta University, Kenya \\ Rosemary James, PhD \\ Senior Lecturer, School of Business, Kenyatta University, Kenya
}

Doi:10.19044/esj.2020.v16n19p457 URL:http://dx.doi.org/10.19044/esj.2020.v16n19p457

\begin{abstract}
This paper explores the influence of project management practices on performance of rural road construction projects in Machakos County, Kenya. Rural road construction projects experience challenges that impede them from being successfully completed within the allocated cost budget, set timelines and to the desired quality. This study specifically investigated how project planning, project execution and project monitoring and control influence the performance of rural construction projects. The study conducted a census of all the 18 rural road construction projects in Machakos County by census. These projects were at various stages of completion. The number of respondents selected was 100 and in order to narrow down on these respondents, simple random sampling technique was used. The study used descriptive and causal research designs and applied a semi-structured questionnaire in collection of data. The study found out that project planning, project execution and project monitoring and control all had a positive and significant relationship with project performance. However, it was also found out that these project management practices were not being applied effectively in the road projects under study. The study concludes that project management practices greatly influence the performance of rural road construction projects. The study recommends that project management practices of project planning, project execution and project monitoring and control which form more than $85 \%$ of the project life cycle, should be effectively applied throughout the life cycle of implementing rural road construction projects in order to ensure that the projects meet the performance goals.
\end{abstract}

Keywords: Key Performance Indicators, Project Life Cycle, Project Management Practices, Construction Project 


\section{Introduction}

Roads form part of infrastructure systems in transportation that support mankind. They form critical links between intended markets, factories and production centres and stimulate economic growth that is manifested in terms of employment opportunities as well as social, health and education. All these are useful in the fight against poverty. While constructing roads costs huge sums of money, without proper maintenance, the roads wear off quickly. This neglect to maintenance of built roads, unfortunately, has been witnessed in many places. The government established Kenya Urban Roads Authority (KURA), Kenya National Highways Authority (KeNHA) and the Kenya Rural Roads Authority (KeRRA) to oversee construction and repair of roads through an Act of Parliament in 2007. KENHA is responsible for national roads, KeRRA oversees rural roads while KURA covers public roads in cities and municipalities which by location and administration have national roads that are excluded in those covered by KURA.

The most common assessment of the performance of construction projects is through evaluating whether the projects have been accomplished on time, within budget, up to the technical specification required and whether they meet client satisfaction. High project performance is achieved when stakeholders meet their individual and collective requirements (Atkinson, Waterhouse and Wells, 1997).

Determination of the performance of road construction projects can be achieved by evaluation of project deliverables against key performance indicators (KPI). These KPIs tell whether the projects are delivered on time, within budget, defect-free, efficiently, right first time, safely and profitably (Vandevoorde and Vanhoucke, 2006). A project is graded as having performed well if is accomplished within budget, gets completed within planned timelines and conforms to functional and technical specifications.

In a project life cycle, the project is started in the initiation phase, then it is actually carried out in a loop through planning, execution, and monitoring and controlling phases and then finally, the work is completed (Williams, 2008).

Project planning establishes a reference for the execution of activities by providing a roadmap that guides the project team. During the planning process, an initial schedule is created that lists all the activities which must be accomplished, the time by which each task must be carried out, the responsible persons for completing each task and the expected deliverables. A fully completed plan is supposed to state what tasks are to be carried out, why the tasks are important, who will carry out what work and when the project is scheduled to be completed. It will also state the resources that are required and in order to be declared complete and successful and what criteria the project must meet (Wysocki and McGary, 2003). 
Project execution puts the project plan to work. It involves organization of the people working on the project, identification of the specific resources required to accomplish the defined work in the plan, allocating the resources to activities, scheduling work and getting the plan launched (Wysocki and McGary, 2003). Project execution is critical because it ensures that resources are allocated and utilized as planned and in the right quantities and right time. It enables teams to be formed and organized in a coordinated way.

The project will not always go according to plan; schedules will often slip. The project must have in place a system that constantly monitors project progress and measures completed work in comparison with the plan and forewarn of any potential problems by looking ahead. This is done in project monitoring and control and is important in projects because it enables the project team to have an understanding of the project progress and thereby have appropriate corrective actions taken when the project performance deviates significantly from plan. In this way, it ensures that the project meets all requirements.

\section{Statement of the Problem}

According to the budget policy statement, 2018, Machakos County was allocated 10.5 billion shillings from the county revenue allocation fund in the 2017/2018 financial year. The statement notes that in 2016/2017, the county spent $44 \%$ on personnel, $29 \%$ on operations and maintenance and $37 \%$ on development.

The development plan for the 2018/19 financial year for Machakos County states that between 2013 and 2017, over 950km of roads were graded; over $56 \mathrm{~km}$ of roads upgraded to bitumen standards; 1,060 metres of drifts (vented and non-vented) constructed; approximately 365 metres of culverts installed and approximately Ksh.12.5 million allocated annually per ward for road maintenance and development.

However, certain road construction projects performed poorly when measured against the time taken, cost and quality. For instance, in the KeRRA annual report for 2016/2017, the Tala-Donyo Sabuk road was expected to cover 70 kilometres in length and be completed in 2018 but was only at $22.29 \%$ completion rate and with only 13.3 kilometres of road length done during the launch year which was the 2016/2017 financial year, the project launch year. The report notes that even though the 80-kilometer MatuuEkalakal-Kangulu road had already been officially launched for construction, work had not yet started. The other highlighted poor performing roads were the Kenol-Ngoleni-Kaani/Mutituni-Kaseve road and the Kimutwa-MakavetiKwamutisya 
The study was guided by the following specific objectives:

i. To evaluate the effect of project planning on performance of rural road construction projects in Machakos County, Kenya

ii. To evaluate the effect of project execution on performance of rural road construction projects in Machakos County, Kenya

iii. To evaluate the effect of project monitoring and control on performance of road construction projects in Machakos County, Kenya

\section{Significance of the Study}

The study will be a helpful resource for such stakeholders as road construction contractors, sponsors and governments because the findings will help in better management and execution of projects. By being aware of the influence of project management to road construction, contractors would leverage on the best practices that improve efficiencies in working and guarantee success.

The findings of this research will be helpful to the government. Roads are a key service provided by the government to its citizens and their construction takes up a huge chunk of the government's expenditure in capital investment and resources required. It is therefore of paramount importance that the government gets the best returns by having completion of the projects within expected timelines, costs and quality standards. The study would be beneficial in ensuring that present infrastructure is improved while the ones planned to be executed in the future incorporate advancements that enhance efficiency and best practices and therefore assure the satisfaction desired by citizens.

It will help policy makers in formulation of new policies and enrich existing ones. It will also form a baseline for creating awareness in adopting best practices for better management and execution of projects for learning institutions.

\section{Theoretical Framework}

The study was underpinned on the theory of constraints, Deming's theory and measurement theory. The theory of constraints (TOC) views any manageable system as being limited in achievement of some or more of its set goals by certain constraints. It recognizes that at least one constraint is present which limits the rate of achievement of goals and therefore buffers should be created to protect synchronizing of processes. The common idiom, a chain is as strong as the weakest link is also adopted in TOC. The theory helps in solving anticipated challenges from constraints such as limited capital, time, materials, skills, machines, systems and policies (Goldratt and Cox, 1992).

Deming's theory is summarized as a repetitive four-stage model for continuous improvement. It follows the PCDA logical sequence model 
defined as Plan-Do-Check-Act. Sokovic, Pavletic and Pipan (2010) state that Plan covers quality concept and objectives, statutory considerations and control of design. Do involves procurement, supplies, servicing, standardization and compatibility. Check uses statistics and charts, inspection and functional testing, quality audits and reviews while Act manages nonconformities and improvements, total quality management and environmental system management. The project manager is able to carry out monitoring and provide corrective measures through continuous evaluation

In the Measurement theory, numbers are assigned to objects. The theory is concerned with the measurable types of things, the relationship between different measures, and the measurement process error problem. According to Cartwright and Bradburn (2015), measurement is assigning values in a grounded and systematic way and not just simply assigning values or numbers. With measurements carried out in the road construction projects, proper inferences can be done that result in correct judgements being made. This would guaranty good performance.

\section{Literature Review}

In a project life cycle, the project is started at the initiation phase, then it is actually carried out in a loop through planning, execution, and monitoring and controlling phases and then finally, the work is completed (Williams, 2008). In this loop, project planning accounts for about $8 \%$ of the total work scope while project execution and project monitoring and control account for about $85 \%$ of the total work scope and therefore these three practices form a big part of the project.

Project planning establishes a reference for the execution of activities by providing a roadmap that guides the project team (Wysocki and McGary, 2003). A project plan is thus developed that has well defined objectives and goals and identifies risks and measures to reduce the impact of those risks and establishes a work plan with clear responsibility matrices for project members. During this phase, stakeholders are involved and defines the project planning tools to be used such as Gantt charts.

Onchoke (2012), in the study to evaluate the factors that influence project performance in community development projects in Kenya evaluated the effect of implementation, monitoring and evaluation, financing and stakeholder involvement. and concluded that performance is greatly influenced by project planning. The findings affirmed that most unsuccessful projects were as a result of poor planning or no planning at all.

Gathoni and Ngugi (2016) in the study on effective project performance drivers in national government CDF funded projects in Kiambu County, Kenya, concluded that the number of project managers who are involved in project management of NG-CDF (National Government 
Constituency Development Fund) projects is low leading to poor performance. This study highlighted why it is important to have project managers involved in planning and implementation of projects but did not cover rural road construction projects.

According to Maendo, James \& Ngugi (2018) in their study to evaluate resource mobilization in projects and road infrastructure project performance on projects constructed by local firms in Kenya, concluded that project resource mobilization and physical, technical and financial resources have a significant effect on performance the projects. The study, however, only focused on resource mobilization and no other project management practices.

Ngundo and James (2018), in their study on the influence of project management practices on government projects implementation in Machakos County, concluded that failure to establish project planning led to failure in successfully implementing the government projects in Machakos County. The study had an R2 of 0.696 and suggested that other researches be carried out to evaluate other independent variables that influence the remaining $30.4 \%$ project management.

Muute and James (2018), in their study on practices in project planning and their influence on construction projects performance in Nairobi County, concluded that time management, financial resource planning as well as human resource planning have an effect on performance of construction projects that is positive and significant. The study, having been carried out in a major city whose dynamics are very different from the rural areas, had conclusions drawn that might not be applicable to the rural settings which have different conditions and challenges.

Project execution involves organization of the people working on the project, identification of the specific resources required to accomplish the defined work in the plan, allocating the resources to activities, scheduling work and getting the plan launched (Wysocki and McGary, 2003). It ensures that resources are allocated in the right quantities and are availed at the right time and that the work is allocated according to the project team members' skills and experiences.

According Maina (2016), the study recommended formulation of operational strategy for implementing health projects which should be the foundational framework that guides project implementation. The study also recommended capacity building before commencement of a project. The study, however, was carried out in a different field of health and also did not cover project planning and project monitoring and control and their influence on implementation.

Wamalwa and James (2018), in their study on critical success factors in the implementation of projects by NGOs in Busia County, evaluated the communication effect on implementation of NGO projects. They evaluated 
the role of financing and examined how local community involvement affects NGO projects implementation. The study found out that information and funding are important components of project implementation for local NGOs and also concluded that local community participation was very critical in any project to guarantee success in implementation. However, the study did not specifically examine the effect of project monitoring and control, project planning and project execution on performance of projects.

In the controlling phase of a project, progress is tracked, and the project adapted to changing circumstances. The most asked question to a project manager is usually to know whether the project is on track (Williams, 2008). This is achieved by constant monitoring and evaluation of how the project is performing when compared between actual and planned progress.

Karanja (2012) in his study on the impact of project management principles on performance of agribusiness projects, established that quality project management practices which include planning, risks assessment, needs establishment, effective and efficient plan implementation, effective organizational framework, monitoring, controlling and evaluation of the projects' results promote the performance of agribusiness projects. However, the study did not evaluate the effect of project planning, project execution and project monitoring and control on road construction projects which this study sought to focus on.

Maendo, James, and Kamau (2018) considered the effect of project monitoring and evaluation on project performance on the road infrastructure projects that are constructed by local firms in Kenya. The study concluded that performance of road infrastructure projects carried out by local firms is significantly affected by project monitoring and evaluation. However, the study did not examine the effect of project planning and project execution on project performance, a gap that was filled by this study.

Wambua and James (2019), in their study on monitoring and evaluation practices and performance, concluded that monitoring and evaluation had the lowest influence on performance of county funded projects in the education sector in Machakos County, Kenya. The study suggested that the independent variables that were studied only explained $62.4 \%$ as the impact of the project monitoring and evaluation practices on performance of education projects that are county funded as indicated by the adjusted $\mathrm{R}^{2}$. The study recommends that further research work be done to study the factors that have an influence on performance that contribute to the remainder of the impact as $37.6 \%$.

In their study on the success factors that are critical in the implementation of community-based projects in Kiambu County, Kenya, Wachira \& James (2018) concluded that monitoring and evaluation is both necessary and sufficiently needed for the implementation of community-based 
projects to be successful. However, the study did not cover the other practices in project management namely project planning and project execution, a gap in study to be filled.

In Kenya, the report by the Commission for Revenue Allocation gives an average of $43.5 \%$ as roads that are deemed good with the remainder, $56.5 \%$, considered as being below performance expectation. Machakos County was rated at having a performance level of $26.9 \%$, a below average performance.

Although other researchers have done related studies, their studies were not focused on the specific project management practices of project planning, project execution and project monitoring and control and their effect on rural road construction project performance. As well, they were not carried out in rural areas that are unique as compared to the areas they studied such as slum areas and urban centres. Therefore, this study was unique because it filled this knowledge gap. Further, it also aimed to determine the effect of project management practices on rural road construction projects in Machakos County, Kenya.

\section{Research Methodology}

The target population consisted of all the completed and ongoing rural road projects constructed or being constructed in Machakos County built as from August 2013 focusing on 18 projects while the respondents were selected from one each of road project construction engineers, prequalified road project contractors, road construction project planners, project auditors and ministry of transport engineers for each road project as well as 10 persons selected from the committees representing the interests on residents of Machakos County the total number being 100. A combination of causal and descriptive research designs was employed.

A questionnaire was used in collecting data in the field and was of the semi-structured type containing open ended as well as closed questions

Both descriptive statistics and inferential statistics were employed in the analysis. The general multiple regression equation used is

$Y=\beta_{0}+\beta_{1} X_{1}+\beta_{2} X_{2}+\beta_{3} X_{3}+\varepsilon$

Where;

$\mathrm{Y}=$ Project performance

$\mathrm{X}_{1}=$ Project planning

$\mathrm{X}_{2}=$ Project execution

$\mathrm{X}_{3}=$ Project monitoring and control

$\beta_{0}=$ Constant term

$\beta 1, \beta 2$, and $\beta 3=$ Regression coefficients

$\varepsilon=$ error term 


\section{Research Findings \\ Descriptive Statistics \\ Project Performance}

To analyze how respondents considered the performance of the road construction projects in Machakos County to be, the research sought their opinion on performance score against time, cost and quality.

Table 4.1: Road Construction Project Performance Parameters

\begin{tabular}{llll}
\hline Parameter & N & Mean & Standard Deviation \\
\hline The projects were completed within budgeted cost & 69 & 2.49 & 0.27 \\
The projects were completed within Planned time & 69 & 2.41 & 0.35 \\
The Road projects were completed to acceptable quality & 69 & 3.38 & 0.62 \\
standards & & & \\
\hline Total & 69 & 2.76 & 0.41
\end{tabular}

Source: Survey data, 2019

From the findings summarized above, majority of the respondents felt that the projects under review were constructed at costs above the budgeted values as affirmed by a low mean of 2.49 and standard deviation of 0.27 . The study also established that majority of the respondents opined that the road construction projects were not completed on time as seen by a low value mean of 2.41 and 0.35 as the standard deviation. Lastly, by a mean of 3.38 and 0.62 as the standard deviation, the study noted that majority of the respondents felt that the road construction projects were not up to acceptable quality standards.

The findings are consistent with Muute and James (2018), who in their study state that project performance is related to client satisfaction and these expectations are usually categorized in three groups; the first is that a stated project creates the expected result with least possible defects; the second is that a given project results in the expected result for the budgeted cost schedule and lastly that a stated project creates the preferred result in the timelines expected. These three performance indicators were used in determining the satisfaction level of the stakeholders against the road projects constructed. From the study, a bigger percentage of respondents stated that the rural road construction projects performed poorly against expectations on timelines, cost and quality. The projects were therefore neither completed on time, within budgeted costs nor at acceptable quality standards.

\section{Project planning and project performance}

To analyze the extent to which project planning influences project performance, the availability of project plans with clear objectives, risks and associated mitigation was measured. Availability and use of responsibility matrices and Gantt charts were also measured. 
Table 4.2 Road Construction Project Planning Factors

\begin{tabular}{|c|c|c|c|}
\hline Parameter & $\mathrm{N}$ & Mean & Standard Deviation \\
\hline $\begin{array}{l}\text { County government involved all stakeholders during } \\
\text { the project planning phase }\end{array}$ & 69 & 2.42 & 0.82 \\
\hline Project plans had clear objectives and goals. & 69 & 3.78 & 0.54 \\
\hline $\begin{array}{l}\text { The project plan identified risks and measures to } \\
\text { reduce impact of risks }\end{array}$ & 69 & 2.77 & 0.48 \\
\hline $\begin{array}{l}\text { There were work plans detailing a responsibility } \\
\text { matrix for project team members }\end{array}$ & 69 & 3.88 & 0.64 \\
\hline $\begin{array}{l}\text { The road construction projects utilized Gantt charts } \\
\text { and time-plans }\end{array}$ & 69 & 3.36 & 0.12 \\
\hline
\end{tabular}

From the findings, the respondents felt that the county government did not involve all stakeholders as seen by the low mean of 2.42 . The study also shows that most respondents stated that the project plans had clear objectives and goals as seen by the mean of 3.78 and also that there were work plans that detailed a responsibility matrix for project team members, affirmed by the scored mean of 3.88. The findings indicated that the respondents believed the project plans did not adequately identify risks and measures to reduce the impact of risks as evidenced by the mean of 2.77 .

The study noted that the road construction projects did not involve stakeholders before commencement of implementation and therefore some stakeholders did not get the chance to have their feedback incorporated in the final design. Majority of the respondents also stated that they did not use project planning tools such as a work plans and Gantt charts that were crucial in determining the sequence of events of the project. These had an influence on the projects.

The findings are consistent with Ngundo and James (2018), who in their study on project management practices and their influence on implementation of government projects in Machakos County, concluded that projects require to have a project plan that clearly states the project goals and objectives in order for them to perform highly.

\section{Project Execution and Project Performance}

To analyze the extent to which project execution influences project performance, the availability of work breakdown structure, allocation of work and manpower distribution and availability of resources were measured. 
Table 4.3: Project Execution Factors in Road Construction Projects

\begin{tabular}{llll}
\hline Project Execution Factor & $\mathrm{N}$ & Mean & Standard Deviation \\
\hline The projects had a work breakdown structure with & 69 & 3.17 & 0.50 \\
The work was allocated manpower according to the & 69 & 2.87 & 0.19 \\
skills and experiences of the team members & & & \\
The resources needed to execute the project were & 69 & 1.99 & 0.69 \\
\hline
\end{tabular}

Source: Survey data, 2019

With a mean of 3.17 , the results showed that the road construction projects had a work breakdown structure. However, it was also noted that manpower was not allocated according to skills and experiences of the team members as seen by the mean of 2.87 . The results of the study also indicated that the resources needed to execute the projects were not availed on schedule and in the required quantities. For this statement, the mean was low at a value of 1.99 .

The study noted that most of the respondents were in agreement that project execution influences the overall performance of projects in the road construction sector. This concurs with Wideman (2014) who states that the execution phase activities represent the biggest part of the project and also where risks assert themselves.

Project execution guarantees successful completion of a project through proper allocation of resources in the desired quantities with manpower provided based on their level of skills and knowledge for each required task. In this phase, the detailed engineering work is performed that results in the engineering drawings upon which the construction project will be based. It also includes procurement of services and materials and the actual construction work done.

\section{Project Monitoring and Control and Project Management}

To analyze the extent to which project monitoring and control influences project performance, marked milestones, periodic tracking and corrections done were measured.

Table 4.4: Project Monitoring and Control Factors in Road Construction Projects

\begin{tabular}{llll}
\hline Project Monitoring and Control Factor & $\mathrm{N}$ & Mean & Standard Deviation \\
\hline There were milestones clearly marked for the projects & 69 & 2.32 & 0.164 \\
$\begin{array}{l}\text { The road construction projects were periodically being } \\
\text { tracked }\end{array}$ & 69 & 1.94 & 0.213 \\
$\begin{array}{l}\text { Corrections were made on the project to steer it back on } \\
\text { track }\end{array}$ & 69 & 2.20 & 0.048 \\
\hline
\end{tabular}

Source: Survey data, 2019

The results showed that the respondents did not feel that there were milestones clearly marked for the projects as seen by the low mean of 2.32. The study also noted that the construction projects were not being tracked 
periodically as seen by the low mean of 1.94 and also noted that corrections were not being made to steer the project back on track as depicted by the mean of 2.20 .

The findings are consistent with Maendo, James and Kamau (2018) who stated that project monitoring and evaluation has a significant influence on performance of road infrastructure projects undertaken by local firms. Their study found out that by regularly conducting monitoring and evaluation, allocating finances for monitoring and evaluation activities sufficiently and employment of staff who have the required skills play a critical role in the performance of road infrastructure projects. Majority of the respondents stated that there was no means of tracking the execution progress and no corrective actions were being done to rectify deviations.

\section{Regression Analysis}

Multiple regression analysis was used to establish the relationship between project management practices and the performance of road construction projects. The regression results are presented in the following sections.

\section{Model Summary}

The findings of the model summary are as illustrated below.

Table 4.5: Model Summary

\begin{tabular}{|l|l|l|l|l|}
\hline Model & R & R Square & Adjusted R Square & Std Error of Estimate \\
\hline 1 & $0.832 \mathrm{a}$ & 0.692 & 0.678 & 0.26655 \\
\hline
\end{tabular}

a. Predictors: (Constant), Project Planning, Project Execution, Project Monitoring and Control Source: Survey Data, 2019

The model summary was used in defining the predictive power of the model. With the adjusted coefficient of determination, $\mathrm{R} 2$, as 0.678 , inferred that $67.8 \%$, of the variations in project performance, the dependent variable, could be attributed to the three independent variables in the study namely project planning, project monitoring and control and project execution. The remaining $32.2 \%$ can be explained by other factors that were not included in the study which affect implementation of projects.

\section{Analysis of Variance}

Table 4.6: Analysis of Variance

\begin{tabular}{llllll}
\hline Indicator & Sum of Squares & df & Mean Square & F & Sig. \\
\hline Regression & 10.367 & 3 & 3.456 & 48.638 & $1.32565 \mathrm{E}-16$ \\
Residual & 4.618 & 65 & 0.071 & & \\
Total & 14.986 & 68 & & & \\
\hline
\end{tabular}

Source: Survey data, 2019 
From the ANOVA output, the p-value is small, less than 0.05, which indicates that the performance of the road construction projects in Machakos County was significantly influenced by at least one of the independent variables under study. Therefore, the overall regression model was significant

\section{Coefficients of the Regression Model}

The regression coefficients are as shown in table 4.7

Table 4.7: Regression Coefficients

\begin{tabular}{|l|l|l|l|l|l|}
\hline \multirow{2}{*}{ Model } & \multicolumn{2}{|l|}{$\begin{array}{l}\text { Unstandardized } \\
\text { Coefficients }\end{array}$} & \multicolumn{2}{l|}{$\begin{array}{l}\text { Standardized } \\
\text { Coefficients }\end{array}$} & \multirow{2}{*}{ P-value } \\
\cline { 2 - 6 } & $\mathrm{B}$ & $\begin{array}{l}\text { Standard } \\
\text { Error }\end{array}$ & Beta & $\mathrm{t}$ & \\
\hline Constant & 0.789 & 0.209 & 0.372 & 3.774 & 0.00035039 \\
\hline Project Planning & 0.209 & 0.040 & 0.290 & 5.216 & 0.00000204 \\
\hline Project Execution & 0.192 & 0.033 & 0.258 & 5.825 & 0.00000019 \\
\hline $\begin{array}{l}\text { Project Monitoring } \\
\text { and Control }\end{array}$ & 0.206 & 0.030 & 0.267 & 6.814 & 0.00000000 \\
\hline
\end{tabular}

a. Dependent Variable: Project Performance

Source: Survey Data, 2019

From the findings, while holding other factors constant, an increase in project planning causes an improvement in project performance. Project planning had a $\mathrm{p}$ value less than 0.05 and therefore is a significance determinant of project performance. This finding is supported by Mkutano (2018), who in his study on project management practices and performance of non-governmental organizations projects in Nairobi City County, Kenya found a positive and significant relationship between performance and project planning. Therefore, the study finding inferred that good project performance score is directly related to good project planning

The findings show that while holding other factors constant, an increase in project execution causes an improvement in project performance. Project execution had a $\mathrm{p}$ value less than 0.05 and therefore project execution is a significance determinant of project performance. At the execution stage, the bulk of the work is carried out including the major activities needed to accomplish the work of the project. It requires time and effort.

In the study on determinants influencing performance of agricultural projects: a case of NALEP projects in Ruiru district, Kiambu County, Kenya, Wangeci (2013), concurs with the study and affirms that project implementation is critical to project performance as it ensures that the plans are put into practice. The researcher further states that $80-85 \%$ of the total 
project work is accounted for in the implementation phase and hence needs to be completed as fast as possible and within least possible resources. This therefore calls for greater need for coordination, monitoring and control along with application of all project management techniques of in this phase including the planning effort, communication management, change management as well as team and team member motivation. At execution stage, the quality of work and cycle time for the project will be highly affected by how effective the project team is in utilizing available resources.

The findings also established that while holding other factors constant, an increase in project monitoring and control causes an improvement in project performance. Project monitoring and control had a $\mathrm{p}$ value less than 0.05 and therefore project monitoring and control is a significance determinant of project performance. The findings are supported by Wambua and James (2018), who in his study on monitoring and evaluation practices and performance of county funded education projects in Makueni County, Kenya, observed that there exists a positive correlation between monitoring and evaluation training and project performance. Further, the study states that if trainings in monitoring and evaluation are increased the performance of county funded projects also improves due to accuracy of feedback got from monitoring and evaluation units.

Overall, project planning had the greatest effect on the performance of rural road construction projects in Machakos County. This was followed by project monitoring and control while project execution had the least effect to the rural road construction projects. All the variables under study were significant with $\mathrm{p}<0.05$ implying that there exists a positive relationship between the independent variables and the dependent variable. Therefore, there is need to incorporate these variables in order for projects to have good performance when implemented.

Through the regression analysis, the study was able to answer conclusively the specific objectives of the research by determining the effect of independent variables (project planning, project execution and project monitoring and control) on the dependent variable (project performance).

\section{Discussion}

The objective of the study was to determine the influence of project management practices on performance of road construction projects in Machakos County, Kenya. The motivation for carrying out the study was that the county had reported a number of road construction projects that failed to meet completion within the expected timelines and budget allocation.

The findings indicated that project planning affects the performance of rural road construction projects. Project planning tools and methodology that involves stakeholder involvement, project plan with clear objectives and 
goals, risks identification and measures to mitigate them, availability and use of work plans and Gantt charts all aid in ensuring good performance of projects.

The findings indicated that project execution affects the performance of rural road construction projects. proper use of work breakdown structures, proper allocation of manpower and resources based on skills, knowledge and experience and availing resources within required timelines and in the right quantities results in successful execution of projects and therefore good project performance.

The findings indicated that project monitoring and control affects the performance of rural road construction projects. If project monitoring and control practices such as using clear milestones, tracking of work progress through comparison of the plan against the actual work done and having corrections carried out in order to return the project on track if any deviations are noted all contribute positively towards project performance.

\section{Conclusion}

From the analysis and discussion, the study concludes that project performance is greatly influenced by project planning. If the project planning phase is carried out well, the possibility of having a well performing project increases. During the planning phase, stakeholders should be involved in order to have their expectations and feedback well put into the project design. As well, planning tools such as work plans and Gantt charts that facilitate proper planning should be used in projects same as project plans that have well defined objectives and goals. The plan should also identify risks and measures to reduce the impact of those risks. Lastly, the study concluded that the project needs a work plan with clear responsibility matrices for project members.

The study concludes that project execution has significant influence on road construction projects. For better performance of projects, resources should be allocated in the right quantities and be availed at the right time. As well, projects need a work breakdown structure with activities broken down for clarity and ease of execution and the work allocated according to the project team members' skills and experiences.

On project monitoring and control, the study concludes that road construction project performance is influenced significantly by project monitoring and control. For better performance, periodic tracking of the project utilizing defined milestones is necessary and, in this way, it would be possible to make corrections as a result of any deviations experienced.

\section{Recommendations}

Project managers are required to establish a project plan that specifies project goals and objectives as recommended by the study. All the resources 
that are required for execution of the project should be identified. Any risks posed to the project and the consequent risk mitigation factors should be identified and established in the project plan. Also recommended by the study is that the project managers would do well when they use project planning tools such as Gantt charts and time plans that assist in running a project successfully.

The project manager should involve the relevant stakeholders throughout the project by in order to clearly understand their expectations and get their feedback. A detailed responsibility matrix for the team members which would define how all project members are related in terms of tasks and reporting lines should be developed. When executing the project, the project managers should ensure that resources are availed and allocated at the right place, time and quantities with deliberate actions taken to manage actual implementation of tasks per plan and includes managing internal and external relationships. Manpower should be allocated according to the skills and experiences of the team members for optimum results.

Project managers need to incorporate use of project monitoring and control tools. This would ensure that the tasks are tracked as they are implemented and if there are deviations, the problems causing the deviations are identified and the corrective actions carried out. In this regard, the study recommends that milestones should be identified that mark the project progress. Tracking can then be done to evaluate actual progress against expected progress and corrections carried out whenever there are deviations.

\section{References:}

1. Atkinson, A. A., Waterhouse, J. H and Wells, R. B. (1997). A stakeholder approach to strategic performance measurement. Sloan Management Review Spring: 25-37.

2. Cartwright, N \& Bradburn, N (2011). A Theory of measurement. (Unpublished study paper) London School of Economics.

3. Gathoni, J. \& Ngugi, K. (2016). Drivers of effective project performance in national government constituency development funded projects in Kiambu County, Kenya. International Academic Journal of Human Resource and Business Administration, Volume 2, Issue 2.

4. Goldratt, E. \& Cox, J (2014). The goal. A process of ongoing improvement, Third Revised Edition, North River Press, Great Barrington, MA 01230, USA.

5. Government of Kenya, Ministry of Finance. (2018). Medium term 2018 budget policy statement.

https://www.treasury.go.ke/component/jdownloads/send/195-budgetpolicy-statement/732-2018-budget-policystatement.html?option=com_jdownloads . 
6. Karanja, J. (2012). Impact of project management principles to performance of agribusiness projects, a case of Kinango District of Kwale County. (Unpublished Masters dissertation), Kenyatta University, Kenya.

7. Kenya Rural Roads Authority. (2017). Annual report for financial year 2016/2017. Nairobi, Kenya.

8. Machakos County Integrated Development Plan II. (2018). County Integrated Development Plans.

https://cog.go.ke/downloads/category/106-county-integrateddevelopment-plans-2018-2022\#

9. Maina, E. (2016). Factors influencing effective implementation of health projects: A case of AMREF health Africa in Kenya. (Unpublished Masters dissertation) University of Nairobi, Kenya.

10. Maendo, D. O., James, R., Kamau, L. (2018). Effect of project monitoring and evaluation on performance of road infrastructure projects constructed by local firms in Kenya. International Journal of Economics, Business and Management Research, Vol. 2. No 04; 2018.

11. Maendo, D. O., James, R., Ngugi, L. (2018). Effect of project resource mobilization on performance of road infrastructure projects constructed by local firms in Kenya. International Journal of Economics, Business and Management Research, Vol. 2. No 01; 2018.

12. Mkutano, S. M. (2018). Project management practices and performance of non-governmental organizations projects in Nairobi County, Kenya. (Unpublished Masters dissertation), Kenyatta University, Kenya.

13. Muute, C. \& James, R. (2019). Project planning practices and performance of construction projects in Nairobi City County, Kenya. (Unpublished Masters dissertation), Kenyatta University, Kenya.

14. Ngundo, P. \& James, R (2018). Project management practices and implementation of government projects in Machakos County, Kenya. International Journal of Economics, Business and Management Research, Vol. 2. Issue 06.

15. Onchoke, N. (2012). Factors influencing the performance of community development projects in Kenya, a case of Kisii Central District. (Unpublished Masters dissertation), Kenyatta University, Kenya.

16. Report of the Auditor General on the financial operations of Machakos County for the period 1 July 2013 to 30 June 2014 [Fact Sheet]. Retrieved from http://www.kebudgetdocs.ipfkenya.or.ke/docs/Machakos\%20County/ 2013-2014/Machakos\%20Auditor\%20General\%20201314(Executive).pdf 
17. Sokovic, M., Pavletic, D. \& Pipan, K. (2010). Quality improvement methodologies - PDCA cycle, RADAR matrix, DMAIC and DFSS. Journal of achievement of materials and manufacturing engineering, Vol. 43. Issue 1.

18. Vandevoorde, S., Vanhoucke, M. (2006). A comparison of different project duration forecasting methods using earned value metrics. International Journal of Project Management, 24, 289-302.

19. Wachira, G. E., James, R., (2018). Critical success factors in the implementation of community based projects in Kiambu County, Kenya. International Journal of Economics, Business and Management Research, Vol. 2. Issues 4.

20. Wamalwa, T. N., James, R., (2018). Critical success factors in the implementation of projects by non-governmental-organization in Busia County, Kenya. Strategic Journal of Business and Change Management, Vol. 5. Issue 2, Article 48.

21. Wambua, C., James, R (2018). Monitoring and evaluation practices and performance of county funded education projects in Makueni County, Kenya. International Journal of Economics, Business and Management Research, Vol. 2.

22. Wangeci, E.N. (2013). Determinants influencing performance of agricultural projects: a case of NALEP projects in Ruiru district, Kiambu County, Kenya. (Unpublished Masters dissertation) Kenyatta University, Kenya.

23. Williams, M. (2008). The Principles of project management, SitePoint Pty. Ltd, Collingwood, Australia.

24. Wysocki, R and McGary, R (2003). Effective project management, Indianapolis, Indiana Wiley Publishing, Inc. 